\title{
Symbol Analysis in the who Selected Song Lyrics
}

\author{
Yan Ardian Subhan' and Calvin Jonathan Funck ${ }^{2}$ \\ English Department, Universitas Pamulang, Tangerang Selatan, Banten ${ }^{1,2}$ \\ E-mail: doseno0184@unpam.ac.id
}

\section{E-ISSN : $2579-4574$}

P-ISSN : 2549-7359

\begin{abstract}
This study focuses on analysing symbols in five song lyrics of The Who. This study aims at finding and analysing the meanings of symbols and the relationship between both points. The design of this study is descriptive qualitative. The data were analysed by using the theory of symbol by Shaw and Frye. The result of this study showed that the symbols in the five song lyrics of The Who are a reflection of the song writer's feeling and experience of life. It is clear that his life biography of a song writer influences the song lyric he wrote.
\end{abstract}

Keywords: Symbol analysis, Shaw and Frye theory, lyrics, The Who

\section{https://ojs.unm.ac.id/eralingua}

\section{INTRODUCTION}

Literature is artistic writings as an expression of human feelings, experiences, ideas, spirit or believes. Through literature human being can express anything to share. They share an interesting work of literature, many kind of literary works are enjoyed by the audience in the form of poems, song lyrics, novels, and plays. Literary work is classified into three genres. They are poetry, prose, and drama. Poetry is written in verse which generally in lines known as stanza. The use of verse simply refers to poems written in rhythmic patterns and lines. Poetry can be classified as epic, lyric and dramatic. According to Klarer (2004) literally, lyric poetry traces its roots back to ancient Greek when a melodic tales about legends were publicly accompanied by the stringed instrument known as lyre or harp. These recitations were structured in a musical or melodic, they were consequently made it into a tradition through generations. Thus the lyric poetry was born. Lyric poetry is a universal language which is highly liked by people nowadays. The components of lyric poetry itself can be enjoyed by the people because it describes the emotional written feelings of the author such as happiness, sadness, madness, etc. Lyric poetry as well means an expression of something that the author has felt in their life. The author creates beautiful attractive and distinctive words of language into a lyric. All of them have been combined as an interesting song. The song can bring the listeners to enjoy the atmospheres as long as the song set in the harmony. According to Nadel (1984), the creative author brings the literary work lives by their interpretative thoughts. The words of the lyric are occasionally difficult to interpret because the author's do not directly share their ideas to the point instead he has symbols. Symbol that made the literary work lives.

Symbol is a form which could be interpreted and it has a specific meaning, for example, rain means tear or depression; therefore, the rain can be called as a symbol. Another example is flower. It is an interpretation symbol of beauty. Flower 
describes beauty of nature. In a literary work, symbol is used to carry greater meaning than its simple presence might indicate. When a symbol is introduced, it is understood to signify the very specific things intended by the writer. In interpreting a symbol, the writer needs to feel and know the significance of the song by the author. Thus, many symbols that contained or recorded in The Who's songs makes it important to be analysed in order to be interpreted and also to understand the purpose of their creation. Symbol in the lyrics of the song express the personal life, surroundings, and thoughts. The five song lyrics selected are I Can't Explain, Baba O'Riley, Behind Blue Eyes, The Seeker, and I Can See for Miles. After the popularity of the Beatles around the world, England reveals many legendary bands including The Who. The Who is an English rock band from Acton, London. The classic line up consists of lead singer Roger Daltrey, guitarist and singer Pete Townshend, bass guitarist John Entwistle and drummer Keith Moon. Most of the song lyrics are written by Pete Townshend.

\section{THEORETICAL REVIEW}

Lyric has become a media and an object in this study based on symbol analysis. The contents of this subchapter explain about the definitions and theories about poetry and lyric and symbol as follows:

\section{Poetry and Lyric}

Poetry is not only a text the author created, but it is also about feeling. The human feeling represents on written or oral work in verses, it represents the emotional such as happiness, sadness, madness, etc. In addition, poetry is a literary work which has special interest that given expressions of feelings and ideas. Poetry has created an imagination or a feeling expressed in a remarkable language preference. According to Painter (1903), poetry is classified into four general types such as didactic poetry which concerned with instruction, lyric poetry which expressed to emotion, epic poetry which devoted into narration, and dramatic poetry which related to direct representation.

Narrative and lyric are the classified elements of poetry. Narrative poetry emphasise on the story and action, whether lyric poetry emphasise on the emotion and song. Lyric poetry is high intimate kind of poetry. It is usually brief, melodic, and harmonic. "Poetry is closely related to the term "lyric" which derives etymologically from the Greek musical instrument "lyra" ("lyre" or "harp") and points to an origin in the sphere of music. Lyric poetry is mainly concerned with one event, impression, or idea and usually short." (Klarer, 2004) According to Klarer's theory, lyric poetry is concerned with a situation, feeling, thought and generally concise. He also argues that lyric come from the Greek musical instrument as an origin in the music scope. Based on those theories above, lyric poetry is more easily understandable because it adds some musical instrument which makes the listeners clearly comprehend the emotional, feeling, and thought of the author.

\section{Symbol}

Symbol is one of elements which usually used in poetry. Poems will often convey on ideas and thoughts using symbols. A symbol can stand for many things at one time and lead the reader out of a systematic and structured method of looking at things. A symbol is often used in the poem and will be used to create such an 
effect. In the song lyric, symbol is used as a tool for the author to describe the process in their lyric. According to Shaw in Fadaee (2011:20) "(Symbol is) something used for, or regarded as, representing something else. More specifically, a symbol is a word, phrase, or other expression having a complex of associated meanings; in this sense, a symbol is viewed as having values different from those of whatever is being symbolized. Many poets have used the rose as a symbol of youth and beauty; a flag is a piece of cloth which stands for or is a symbol of a nation".

It can be inferred that there may be different opinion or perception to represent the symbol, it depends on how the context of the poem. Literary work can be interpreted through contextual reading where phases are themselves regarded as contexts. They are fundamentally meant to describe critical procedures rather than literary types, then, they reflect methods for analysing symbol meaning. According to Frye (1957) symbol is used to mean any unit of literary structure which can be isolated for critical attention. The definition links up the appropriate kind of symbolism which each phase define the phase at the highest level of generality.

\section{RESEARCH METHOD}

Qualitative approach has been chosen as an appropriate method to be used in the analysis of this study. It means the data are collected and classified by read the song lyrics, and these data are a part of qualitative data as they are in word form. Besides, they are identified based on symbol and theme. Creswell (2014) states that qualitative research is an approach for exploring and understanding the meaning individuals or groups ascribe to a social or human problem. Data analyse inductively building from particulars to general themes, and the researcher is making interpretations of the meaning of the data.

Qualitative approach focused on interpreting the meaning of the data from individuals or groups. Hence, the method becomes a guideline of the study to help the writer on arranging and interpreting the contents in a relevant form according to the data that is being collected and the theory is being applied in this study. The data source used in this study were taken from selected five song lyrics from a rock band The Who which are: I Can't Explain, Baba O'Riley, Behind Blue Eyes, The Seeker, I Can See For Miles. In collecting the data for this study, the writer used many ways such as choosing, reading, finding, and searching the object in the internet. The writer collected the data in the form of lyric from songs. Before determining the data, the song lyrics have to be read completely and repeatedly, in order to make sure the words, phrases and sentences from the song lyrics are interpretable. Further, the writer classified the data and analysed them based on symbol discovered in the song lyrics.

\section{RESULT AND DISCUSSION}

After analysing the symbols in selected song lyrics of The Who, some points are concluded. The song lyrics are written by Pete Townshend, the lead guitarist of The Who. There are also deep relationships between the song lyrics and the biography of the author. It can be seen the intended meanings of the symbols in the song lyric by knowing the biography of the author. The writer founds 36 symbols in 
the song lyrics. Feelings, events, and issues that are experienced by the author give influenced in determining what to be written in a song lyric.

\section{Symbols Analysis in “Baba O'Riley”}

Pete Townshend wrote Baba O'Riley song lyric for his Lifehouse project, a rock opera that was be the follow-up to the Who's 1969 rock opera, Tommy. When Lifehouse project was scrapped, eight of the songs were salvaged and recorded for the Who's 1971 album "Who's Next", with this song as the lead-off track. There are five symbols found in the song lyric of Baba O'Riley. The symbols are "Fight for My Meals" in the second line, "My Living" in the third line, "Teenage Wasteland" in the ninth line, "Happy Ones" in the fifteenth line, and "Get Much Older" in the seventeenth line. Baba O'Riley lyric is about a journey of teenage farmers who were going to England to attend a concert. He wrote this song based on his experience of life and made it into a story. The story is about a journey of a few farmers that are mainly teenager from Scotland and they were going to attend a music concert in England. They travelled by a vehicle across polluted place on England called wasteland. A symbol is found in the second line, "Fight for My Meals." Fight, in term, means struggle to something important. But in this lyric "Fight for My Meals" means staying alive, like he must keep alive to survive in this world because life was so hard and full of obstacles. Townshend and this lyric had a relation because he must survive when he did not live with his parents at age of 20 after he went to the college and formed a band before The Who.

Another symbol found is in line three, "My Living." It literally means his life, but in this lyric "My Living" means home. Line three is written as "I get my back into my living." It clearly states that he wants to go home because he was suffered with his life at the time. His old band was not popular enough in his college and he was looking for another lead vocalist but need more money to recruit. In the ninth line there is "Teenage Wasteland" stand as a symbol. It means a desolation place in England that the teenage farmers' cross to get to the concert. They are from Scotland which the air was not polluted as in England because they were living in a remote area of Scotland. There is also a symbol "Happy Ones" in line fifteen that means a concert. In the story that Townshend made, the teenage farmers were going to a concert in England. The happy ones here were symbolised as a concert. They travelled far enough across the wasteland and finally arrived at the concert. Another symbol is in sentence "Before we get much older" written in line seventeen. The words "get much older" mean late of something. Thus, the seventeenth line states about what we must do before it is too late and we will not have good experience as travelling from Scotland to England.

\section{Symbols Analysis in "The Seeker"}

There are eight symbols have been found in the song lyric. The symbols are "Fifty Million Fables" in the fourth line, "Won't Get to Get What I'm after Till the Day I Die" in seventh to eighth line, "The Seeker" in the thirteenth line, "Low and High" in the fourteenth line, "Ransack Their Homes" in the nineteenth line, "Focusing on Nowhere, Investigating Miles" in twenty-first to twenty-second line, "Got Values But I Don't Know How or Why" in the thirteenth line, "I'm Looking for me, and You're Looking For You" in thirty-first to thirty-second line. The first symbol is "Fifty 
Million Fables" which can be found in the fourth line of the song lyric. It is included a sentence "I've tried to find the key to fifty million fables". It means he is looking for an answer of his life through religion and philosophy as Townshend had a mentor in philosophy, Meher Baba.

In seventh to eighth line there is a sentence "Won't Get to Get What I'm after Till the Day I Die" as a symbol. The lyric described what Townshend felt at the time. He was unable to believe in something before he met his future mentor in philosophy, thus he never believes how to live till he has live it and dies. His thought was changed when he met Meher Baba that gave him more strength of spiritual in life. Another symbol found is in the line number thirteen, "The Seeker". It means he is looking for the meaning of life. Townshend still confused and did not understand about his life as a popular person, thus he was looking for an answer as he described it in the third stanza "I asked Bobby Dylan, I asked the Beatles, I asked Timothy Leary, but he couldn't help me either."

Another one is a symbol "Low and High" in line fourteen, it means that he was looking for the answer everywhere as written fully in the fourteenth line of the lyric "I've been searching low and high." Townshend has looked everywhere for the answer his curiosity. He still gets nothing in his search even though he was looking everywhere as far as he can. In line nineteen there is "Ransack Their Homes" as symbol. When Townshend focuses on his curiosity, there were few persons who did not noticed about it. Thus, he was going to get attention from them so he described it in the lyric "As I ransack their homes, they want to shake my hand." There is a symbol in sentence "Focusing on Nowhere Investigating Miles" in line twenty-one to twenty-two. Townshend was getting frustrated and going to escape from his curiosity as he written in the lyric. In line twenty-four he also mentioned that he is a desperate man. He was not yet find what he was looking for thus he got frustrated of it.

Another symbol found is "Got Values but I Don't Know How or Why" in the thirteenth line. When Townshend found his answer with the help of his mentor, it seems meaningless. He did not know how should he do and why he should do to face his popularity. He described it as he was looking for something meaningless all that time. It is "I'm Looking for me, You're Looking For You" written in line thirtyfirst to thirty-second categorized as a symbol. It described a selfishness of Pete Townshend. He realised that he was a selfish man once at the time. According to Townshend (2012), "I am the childish, devilish, and selfish as a reptilian life of a rock star." The lyric of "The Seeker" is about Townshend personality as a musician when he was in a desperate moment of his life. His spiritual mentor, Meher Baba played an important role in Townshend's life that made him changed his habit and became a better person to face the problems. The song lyric is about desperation and how it does to a person like Pete Townshend as a lead guitarist of the band. However, this is not his favourite song but this song is so popular until this time along with the popularity of The Who.

\section{Symbols Analysis in "I Can See For Miles"}

This song was released as a single in 1967 and recorded for the album "The Who Sell Out" in the same year. It was the only song from the album to be released 
as a single. There are seven symbols that have been found in the song lyric. The symbols are, "Magic in My Eyes" in the second line, "I Can See for Miles" in the third line, "Little Tricks" in the fifth line, "Lose That Smile" in the ninth line, "Took Advantage" in the fifteenth line, and "Mine to See" in the thirteenth line. The first symbol is "Magic in My Eyes" in the second line. Magic, in term, means something in relation with sorcery and spell, but in this lyric, magic can be interpreted as an ability to see things. Thus the symbol in the second line means I know everything you did and you cannot lie to me. Townshend described it as he knows everything she did and it referred to his wife, Karen Townshend.

The second symbol found is "I Can See for Miles" in the third line. It means even though he was very far from his wife, he could still keep an eye on her and he knows if she was playing on him. Thus, it would be a reminder to his wife, Karen Townshend that he would know everything she does behind him. The third symbol found is "Little Tricks" in the fifth line. It literally means like a magic show that have a little trick with a rabbit inside a hat, but in this lyrics it would not say so. It would be clearly with the full line as written "if you think that I don't know about the little tricks you've played." It means he know that she was lying to him, little tricks here mean lying. There is another symbol found in the ninth line written fully as "You're Gonna Lose That Smile, Because All The While." The symbol "Lose That Smile" means he would not care anymore with her and she would lose his love because everything she probably did on him. Townshend described it as a warning to her.

There are two symbols found in line number fifteen, the first is "Took Advantage" it means she is freely to cheating and the second symbol is "Far Away" it means on duty. Thus, the possible meaning of line fifteen is she was freely cheated on him while he was on duty at tour. Townshend described it as his wife was freely to bunch up with another guy while he was not beside her. Another symbol found is "Mine to See" in line number thirteen. The thirteenth line written as "The Eiffel Tower and The Taj Mahal are mine to see on Clear Days" it means he can see her even though he is miles away from her and she cannot get out of his sight. Karen Townshend rarely accompanied his husband when he was left to tour. Townshend made this song to remind his wife to not cheating on him. This song lyric is about a suspiciousness of Pete Townshend to his wife whom he always left when he got a tour.

\section{Symbols Analysis in "I Can't Explain"}

The song is one of The Who's single in 1965 and the first song on their popular compilation album, "Meaty, Meaty, Big and Bouncy" in 1971. There are nine symbols have been found in this song. The symbols are, "Got a Feeling Inside" in the first line, "Hot and Cold" in the third line, "Down in My Soul" in the fourth line, "Dizzy in the Head" in the seventh line, "Funny Dreams" in the ninth line, "Can't Explain" in the eleventh line, "Feel Blue" in fourteenth line, "Drive Me Out of My Mind" in the twenty-eighth line, and "Worrying Kind" in the twenty-ninth line" The first symbol found is "Got a Feeling Inside" which is in the first line. The feeling inside can be interpreted as a love to his girlfriend. Townshend described it as a love for his girlfriend that would be his future wife, Karen Townshend. 
The second symbol found is "Hot and Cold" in the third line. It is written in a sentence "I feel hot and cold." It could be interpreted as he feels not just about love but also a frustrating feeling about his drugs habit while he was falling in love with a woman. Townshend wrote this song when he was 18 years old and as a teenager that felt love for someone but also addicted to drugs. The third symbol is "Down in My Soul" in line four. It symbolized a deep feeling for his girlfriend. Townshend described it as an emotional feeling to Karen in his heart. It would be described as she was the one he loved with all his heart.

Another symbol found is "Dizzy in the Head" in line seven. It symbolised what he felt about drugs. Townshend consumed too much a mood altering drug called Dexedrine. It made him did not know how to say love or to express his feeling to his girlfriend. There is another symbol "Funny Dreams" in line number nine. Townshend described it as his thought about Karen. He was always thinking about her and cannot get out of his mind because he was falling in love with her and he adored her. It is like no other women that can replace her in his heart because she was already in his mind. In line number eleven there is a symbol written "Can't Explain." Eventually this word is pronounced in every stanza and it symbolised as his love but he cannot find a way to explain that he loves his girlfriend that's why he made it as a symbol.

In line fourteen there is a symbol "Feel Blue." It is interpreted as his sadness. To his girlfriend he cannot say that he loves her because he was affected by drugs, thus he cannot express what he feels to her and he got sad about the reality of his romance. Another symbol found is "Drive Me out of My Mind" in line twenty-eight. Townshend described it as his feeling was annoyed and bothered him. He was always thinking about his girlfriend and she cannot get out of his mind, thus this feeling annoyed him. The last symbol found in the lyric is "Worrying Kind" in line number twenty-nine. Even though his feeling about her bothered him, but he also feels afraid if his feeling will bother her either. He still cannot find a way how to tell her if he loves her until he got free from consuming drugs. In the end, the song lyric is about a young boy who were unable to express his feeling to his girlfriend.

\section{Symbols Analysis in "Behind Blue Eyes"}

Seven symbols are found in this song lyric. The symbols are, "None One Knows What It's Like" in the first line, "Behind Blue Eyes" in the fourth line, "Telling Only Lies" in the eighth line, "I Have Hours, Only Lonely" in the twelfth line, "No One Bites Back as Hard on Their Anger" in eighteenth to nineteenth line, "Laugh and Act Like a Fool" in the twenty-second line, and "Let Me Wear Your Coat" in the twenty-sixth line. The first symbol is "No One Knows What It's Like" in the first line. It described about how Townshend feel lonely in his life because no one noticed and knew him better. According to Townshend (2012), no one knows him as a person who has high expectations and pressure to be someone he is not.

The second symbol "Behind Blue Eyes" is in line four. It described his sadness because no one fells for him. Townshend felt everybody ignored him because he was expecting too much and it made him disappointed after knowing his expectation failed. The third symbol in line eight is "Telling Only Lies." It means that he got nobody trust. He assumed that telling lie was a better option but he caught 
in the lie and he end up being the one that nobody trusts. The fourth symbol is "I Have Hours, Only Lonely" in line twelve. It described about how Townshend felt like when most people around him dislike him. He spent a lot of time thinking about why things went wrong. Another symbol found in line number eighteen to nineteen is "No One Bites Back as Hard on Their Anger." It can be interpreted as he hides his emotions from everyone, thus he can avoid the situations which cause him to be hated. Townshend just had a feeling that everyone hates him.

There is another symbol found in line number thirty-two "Laugh and Act Like a Fool." Townshend described it as an expression that came out at inappropriate moment. It would make him looked worse and became the attention of others. The last symbol found is "Let Me Wear Your Coat" in line thirty-six. This symbol means selfishness. The complete sentence written is "Keep Me Warm, Let Me Wear Your Coat." It described him as only care about himself and forget people around him. He feels like he has a power as a musician but in the other side he feels lonely because no one understands what he wants.

\section{CONCLUSION}

Based on the analysis of symbols in The Who selected song lyrics, it can be inferred that the song lyrics were based on life experiences of Pete Townshend as a young teenager, a lover to his girlfriend, and also a famous musician in The Who. The symbols found were originally described the feeling of the author that create an implicit meaning into the lyrics, thus the lyrics has a beautiful distinctive words. The first lyric is Baba O'Riley that generally tells about a journey of teenage farmers who were going to England to attend a concert. The story which Townshend created was based on his life. He combined his life experience and the story that he created about teenage farmers who were going to England by a vehicle from Scotland through the most polluted place on England called wasteland to attend a music concert. The journey that they passed was not easy as what other people think.

The second lyric is The Seeker, it is a song about desperation of the song writer, Pete Townshend. He was once got desperate because he was looking for an answer about his life as a popular musician. He had dilemma about how to handle his successes with his band, then he met Meher Baba and he became his apprentice in philosophy. Meher Baba helps him to figure out his problems about life and he was the one who influenced Townshend's career in the future. The third lyric I Can See for Miles is about a suspiciousness of Pete Townshend to his wife whom he always left when he got a tour. He loved his wife Karen very much but when he travelled, he got suspicious for her. It would probably he got jealous when his wife bunch up with another guy.

The fourth lyric is I Can't Explain. It is about a young boy who were unable to express his feeling to his girlfriend because he was taken too much drug. Townshend wrote this song when he was 18 years old and he was a young boy who was unable to express his feeling to Karen, his girlfriend. The last lyric is Behind Blue Eyes, it tells about how lonely it is to be popular. His power and popularity as a musician and band leader oppositely made him feel lonely because he was a person who had a high expectation in something. He has a high self-confidence that made 
him would not listen what other people think about him. Other people cannot feel what he feels and he was the only one who can understand himself.

\section{REFERENCES}

Creswell, J. W. (2014). Fourth Edition Research Design Qualitativ, Quantitative, and Mixed Methods Approaches. California: SAGE Publications, Inc.

Fadaee, E. (2011). Symbols, Metaphors and Similes in Literature: A Case Study of "Animal Farm". Journal of English and Literature Vol. 2, 19-27.

Frye, N. (1957). Anatomy of Criticism. New Jersey: Princeton University Press.

Kennedy, X. J. (1983). Literature: An Introduction to Fiction, Poetry, and Drama Third Edition. New York: Little, Brown.

Klarer, M. (2004). An Introduction to Literary Studies. London: Routledge.

Nadel, I. B. (1984). BIOGRAPHY: Fiction, Fact, and Form. London: The Macmillan Press LTD.

Painter, F. V. (1903). Elementary Guide to Literary Criticism. Boston: Ginn Company.

Perrine, L. (1991). Sound and Sense: An Introduction to Poetry. New York: Harcort College Publisher.

Shaw in Fadaee, E. (2011). Symbols, Metaphors and Similes in Literature: A Case Study of "Animal Farm". Journal of English and Literature Vol. 2, 19-27

Townshend, P. (2012). WHO I AM. New York City: Harper Collins. 